\title{
Model Pembelajaran SAVI Berbantuan Media Mind Mapping Meningkatkan Hasil Belajar IPA Siswa Kelas V
}

\author{
I Gede Eric Cantona', I Komang Sudarma² \\ ${ }^{1}$ Program Studi Pendidikan Guru Sekolah Dasar, Universitas Pendidikan Ganesha \\ Singaraja, Indonesia \\ 2Program Studi Teknologi Pendidikan, Universitas Pendidikan Ganesha \\ Singaraja, Indonesia \\ e-mail:cona.ost@gmail.com, sudarmadede@gmail.com
}

\begin{abstract}
Abstrak
Hasil belajar IPA sebagian besar siswa yang masih rendah, mendorong perlunya menciptakan proses pembelajaran yang dapat mengatasi permasalahan tersebut. Salah satu cara yaitu dengan menggunakan model pembelajaran SAVI berbantuan media mind mapping. Tujuan dari penelitian ini untuk mengetahui pengaruh model pembelajaran SAVI berbantuan mind mapping terhadap hasil belajar IPA di kelas V. Penelitian ini merupakan penelitian quasi eksperiment dengan menggunakan rancangan non-equivalent posttest onlycontrol group. Adapun jumlah dari populasi dalam penelitian ini 104 siswa dan sampel penelitian berjumlah 40 siswa yang diambil menggunakan teknik cluster random sampling. Data hasil belajar IPA dianalisis menggunakan uji-t. Hasil analisis uji-t menunjukkan data yang diperoleh thitung $=2,86>$ tabel pada taraf signifikan $5 \%$ dan dk 38 diperoleh nilai tabel $=2,02$. Hal ini menunjukkan bahwa terdapat pengaruh yang signifikan model pembelajaran SAVI berbantuan media mind mapping terhadap hasil belajar IPA siswa kelas V. Dengan demikian model pembelajaran SAVI berbantuan media mind mapping memberikan pengaruh positif terhadap hasil belajar IPA siswa kelas V. Implikasi pada penelitian ini adalah pembelajaran menggunakan model pembelajaran SAVI berbantuan media mind mapping sesuai untuk diterapkan pada pembelajaran IPA karena dengan menerapkan model pembelajaran SAVI ini membuat siswa belajar dengan menemukan pengalaman-pengalaman baru yang nantinya akan meningkatkan keaktifan, berpikir kritis, serta daya ingat yang semakin berkembang. Sehingga hal tersebut akan berpengaruh terhadap hasil belajar IPA yang dimiliki oleh siswa.
\end{abstract}

Kata kunci: SAVI, Mind Mapping, IPA

\begin{abstract}
Science learning outcomes are mostly low students, encouraging the need to create a learning process that can overcome these problems. One way is to use SAVI learning models with the help of mind mapping media. The purpose of this study was to determine the effect of SAVI learning models assisted with mind mapping on learning outcomes of Natural Sciences in class V. This study was a quasi experimental study using a nonequivalent posttest only control group design. The number of population in this study was 104 students and the study sample was 40 students taken using cluster random sampling techniques. Science learning outcomes data were analyzed using t-test. The results of the t-test analysis showed that the data obtained tcount $=2.86>t_{\text {table }}$ at a significant level of $5 \%$ and $\mathrm{dk} 38$ obtained $t_{\mathrm{tabl}}=2.02$. This shows that there is a significant influence on the SAVI learning model assisted with mind mapping media on the learning outcomes of the fifth grade science students. Thus the SAVI learning model assisted with the mind mapping media has a positive influence on the learning outcomes of the fifth grade students' natural science learning. The implication in this study is learning using SAVI learning models assisted with mind mapping media are appropriate to be applied to science learning because by applying this SAVI learning model makes students learn by discovering new experiences that will later increase the activeness, critical thinking, and
\end{abstract}


growing memory. So this will affect the learning outcomes of Natural Sciences owned by students.

\section{Keywords: SAVI, Mind Mapping, science}

\section{Pendahuluan}

Pendidikan di sekolah dasar memberikan suatu pemahaman dasar tentang semua mata pelajaran termasuk mata pelajaran IPA (IImu Pengetahuan Alam). "IPA berasal dari bahasa inggris yaitu Science yang berasal dari singkatan Natural Science. Natural yang dapat diartikan sebagai alamiah atau yang berhubungan dengan alam dan science yang dapat diartikan sebagai ilmu pengetahuan" (Sudana, 2016) pendapat tersebut sejalan dengan Malawi, I., dan Juwarti (2013) menyatakan bahwa Ilmu pengetahuan alam yaitu berasal dari Bahasa Inggris yang terjemahan kata-kata yaitu natural science, yang artinya ilmu pengetahuan alam (IPA). Widyanto (2016) menyatakan bahwa IPA adalah suatu pengetahuan tentang sistematika alam yang memuat tentang gejala-gejala alam dan peristiwa-peristiwa alam yang bukan hanya memuat fakta namun memuat sikap ilmiah dan metode ilmiah. Jadi, IPA dapat dikatakan sebagai ilmu yang mempelajari tentang alam semesta beserta seluruh isinya. Sedangkan Bundu (2006) menyatakan hakikat IPA dapat diklasifikasikan menjadi tiga yaitu: IPA sebagai proses, sebagai produk, dan IPA sebagai sikap ilmiah. Berdasarkan hal tersebut, terlihat bahwa IPA sangat terkait dengan kehidupan sehari-hari, sehingga IPA bukan hanya ilmu yang bersifat hafalan saja tetapi proses menemukan sesuatu. Proses pembelajaran IPA meminta siswa untuk terjun langsung sesuai langkah-langkah yang sistematis sehingga memperoleh penemuan baru dan mencapai tujuan dengan efektif (Ariyanto, 2016).

Mengingat pentingnya pembelajaran IPA, maka sangat baik apabila IPA dibelajarkan sejak usia sekolah dasar. Pemerintah mengharapkan pendidik mampu membuat pembelajaran yang aktif, efektif, dan menyenangkan.Aktif yang dimaksud adalah aktif dalam mengikuti pelajaran yang memusatkan siswa pada proses pembelajaran berlangsung, sehingga proses pembelajaran optimal, sedangkan efektif yang dimaksud adalah penyampaian materi yang akan disampaikan tidak memerlukan waktu terlalu banyak yang penting tujuan dari materi tersebut tersampaikan dengan jelas, dan menyenangkan yang dimaksud adalah dalam proses pembelajaran siswa diharapkan mampu mengikuti pembelajaran dengan baik dan peran dari pendidik sangat besar dalam mengelola serta memberikan pelayanan saat proses pembelajaran agar pembelajaran berjalan dengan baik, sehingga anak dekat dengan guru dan suasana kelas tidak membosankan (Uno \& Nurdin dalam Fatmah, A. N., dkk., 2018). Selain itu pendidik juga harus dapat memotivasi siswa dalam proses pembelajaran, sebab pada umumnya sebagian besar siswa tidak senang dengan pembelajaran IPA, karena IPA sebagaian besar materinya merupakan materi hafalan. Jika seorang pendidik dalam proses pembelajaran IPA di sekolah dasar tidak mampu membuat suasana pembelajaran menjadi aktif, efektif, dan menyenangkan, maka siswa akan cenderung bosan dalam mengikuti pembelajaran yang diberikan oleh pendidik. Dampak yang akan terjadi adalah penurunan pemahaman siswa dalam mata pelajaran IPA yang akan berpengaruh terhadap hasil belajar siswa. Selain itu, dampaknya juga akan berpengaruh terhadap semangat yang dimiliki oleh siswa dalam proses pembelajaran.

Tetapi, kenyataanya belum sesuai harapan karena hasil belajar IPA siswa saat ini masih tergolong rendah. Hasil PISA (The Programme for International Student Assessment) menunjukkan bahwa kemampuan dari siswa Indonesia dalam menyelesaikan soal-soal PISA masih jauh di atas rata-rata. Pada PISA 2015 menunjukkan hasil belajar IPA siswa-siswi Indonesia masih tergolong rendah. Berturut-turut rata-rata skor pencapaian siswa-siswi Indonesia untuk sains, membaca, dan matematika berada di peringkat bawah yaitu 62, 61, dan 63 dari 69 Negara (Pratiwi, 2019). Hasil belajar siswa yang tergolong rendah juga yang ditunjukkan dari hasil survie Program for International Student Assessment (PISA) tahun 2018 untuk kategori sains, Indonesia berada pada peringkat 71 dari 80 negara yang mengikuti program ini. Skor rata-rata Indonesia adalah 398 yang terpaut sangat jauh dengan China yang berada di peringkat pertama dengan skor rata-rata 590 (Permana, Rakhmad, 
2019). Hasil belajar siswa yang tergolong rendah juga yang ditunjukkan dari hasil penilaian Trends in International Mathematics and Science Study (TIMSS) tahun 2015 khususnya untuk bidang sains Indonesia berada pada peringkat 45 dari 48 negara. Rata-rata skor Indonesia adalah 397. Jika dibandingkan dengan kriteria capaian TIMSS, maka rata-rata skor Indonesia tergolong pada kategori rendah (Hadi, S., dan Novaliyosi, 2019). Rendahnya kemampuan IPA berdasarkan observasi Hutauruk, P., dan Rinci (2018) yang dilakukan di kelas IV SD Nomor 14 Simbolon Purba, dikarenakan pembelajaran yang dilakukan cenderung masih menggunakan metode ceramah, sehingga peserta didik hanya sebagai penonton saja dan melakukan aktivitas apabila diberikan perintah serta mengerjakan soalsoal latihan dari buku. Slameto (dalam Hutauruk, P., dan Rinci, S., 2018) menyatakan bahwa, apabila guru secara terus menerus menggunakan metode ceramah saja, akan mengakibatkan siswa cepat bosan, mengantuk, pasif dan hanya mencatat saja, sehingga akan berpengaruh terhadap hasil belajar IPA siswa. Selain itu, pada penelitian Suminar (2018) di kelas V SD Negeri Kepuh, dianalisis buku teks IPA yang dipakai, bahwa kurang sesuai dengan karakteristik siswa SD, pada buku sebagian besar berisi teks abstrak dengan bahasa yang baku. Ilustrasi-ilustrasi yang disajikan pada buku masih terlalu abstrak dan kurang menggamarkan materi yang disampaikan. Persoalan lain yang umumnya dialami di SD yaitu pembelajaran yang dilaksanakan guru sangat jarang melkukan kegiatan eksperimen dan sangat minim menggunakan alat peraga, sehingga berpengaruh terhadap peningkatan mutu pendidikan Sains di SD (Fiteriani, I.., dan Baharuddin, 2018). Dilapangan, hasil belajar IPA tergolong rendah yaitu di SD Gugus III Kecamatan Tegallalang sesuai dengan hasil observasi dan pencatatan dokumen yang telah peneliti lakukan pada tanggal 19-23 Oktober 2019 yang diperoleh dari data hasil belajar siswa pada mata pelajaran IPA dengan nilai Ujian Tengah Semester (UTS). Nilai UTS siswa dapat dilihat pada Tabel 1 berikut.

Tabel 1.Hasil Nilai UTS IPA siswa kelas IV SD Gugus III Kecamatan Tegallalang Tahun Pelajaran 2019/2020

\begin{tabular}{cccccccc}
\hline No. & Nama Sekolah & KKM & $\begin{array}{c}\text { Jumlah } \\
\text { Siswa }\end{array}$ & \multicolumn{2}{c}{$\begin{array}{c}\text { Siswa yang } \\
\text { Mencapai KKM }\end{array}$} & \multicolumn{2}{c}{$\begin{array}{c}\text { Siswa yang Belum } \\
\text { Mencapai KKM }\end{array}$} \\
\hline & & & & Siswa & $\%$ & Siswa & $\%$ \\
\hline 1 & SD No 1 Sebatu & 75 & 21 & 10 & $48 \%$ & 11 & $52 \%$ \\
\hline 2 & SD No 2 Sebatu & 75 & 16 & 6 & $37 \%$ & 10 & $62 \%$ \\
\hline 3 & SD No 3 Sebatu & 75 & 17 & 5 & $29 \%$ & 12 & $70 \%$ \\
\hline 4 & SD No 4 Sebatu & 75 & 19 & 7 & $36 \%$ & 12 & $64 \%$ \\
\hline 5 & SD No 5 Sebatu & 75 & 31 & 12 & $38 \%$ & 19 & $61 \%$ \\
\hline \multicolumn{2}{r}{ Total } & & 104 & 40 & $38 \%$ & 64 & $61 \%$ \\
\hline
\end{tabular}

Berdasarkan Tabel 1. hasil belajar IPA menunjukkan sebagian besar siswa yang belum mencapai KKM sebesar $61 \%$ dari 104 siswa. Melihat hal tersebut, maka dirasa perlu untuk menerapkan model yang sesuai dalam proses pembelajaran, sehingga pembelajaran yang dilakukan di dalam kelas dapat efektif, kreatif dan menyenangkan supaya siswa mampu menguasai materi dengan baik khususnya pada pelajaran IPA. Pada proses pembelajaran sangat diperlukan penggunaan suatu model yang sesuai dan tentunya dapat melibatkan seluruh anggota tubuh siswa untuk meningkatkan perhatian siswa dalam belajar. Salah satu model pembelajaran yang dapat digunakan untuk meningkatkan hasil belajar siswa adalah model pembelajaran SAVI (Somatic Auditory Vizualitation Intellectualy). Meier (2004:90) menyatakan model pembelajaran SAVI merupakan suatu model yang dapat mempergunakan seluruh alat indra dan emosi dalam proses belajar. Somatic artinya belajar dengan melakukan gerak dan berbuat, Auditoryadalah belajar berbicara dan mendengarkan, visual artinya belajar dan mengamati, Intellektual artinya belajar dengan proses memecahkan masalah dan menerangkan kembali hasil dari masalah yang ditemui. Dalam proses pembelajaran Intelektual akan menantang siswa untuk berfikir secara kritis dalam 
memecahkan masalah yang diberikan oleh guru. Pembelajaran SAVI berasaskan aliran ilmu kognitif modern, yang berpendapat bahwa belajar yang paling baik adalah melibatkan emosi, seluruh tubuh, semua indera dan segala kedalaman serta keluasan pribadi, menghormati gaya belajar setiap individu dengan menyadari bahwa orang belajar dengan cara yang berbeda (Indrawan, K. A., dkk., 2018). Adapun kelebihan model pembelajaran SAVI adalah membangkitkan kecerdasan terpadu siswa secara penuh melalui penggabungan gerak fisik dengan aktivitas intelektual, didesain agar suasana belajar menjadi menyenangkan, menarik, sehingga siswa tidak mudah lupa karena semua proses pembelajaran tersebut melekat pada diri mereka, mampu membangkitkan kreativitas dan meningkatkan kemampuan psikomotor siswa, memaksimalkan ketajaman konsentrasi siswa, siswa akan termotivasi untuk belajar lebih baik, melatih siswa untuk terbiasa mengemukakan pendapat, bertanya, maupun menjawab, dan kelebihan yang sangat kuat adalah merupakan variasi yang cocok untuk semua gaya belajar (Alfiani, D. A., 2016).

Wisudawati \& Sulistyowati (dalam Devitasari, 2019) memberikan penjelasan bahwa IPA di sekolah harus dapat memberikan akses kepada siswa untuk mengkontruksi sendiri konsep-konsep pengetahuan yang sudah dimiliki siswa. Pada model SAVI siswa akan diberikan kesempatan mengkontruksi pengetahuan dengan alat bantu indra yang dimiliki siswa. Wardani (dalam Indrawan, K. A., dkk., 2018) menyatakan pembelajaran IPA menekankan pada kegiatan belajar yang dapat memberikan pengalaman langsung, agar kompetensi siswa dapat berkembang, sehingga dapat menjelajahi dan memahami lingkungan sekitar secara ilmiah. Hal ini sesuai dengan kebutuhan siswa dan akan dapat menumbuhkan minat dan meningkatkan hasil belajar siswa.

Berdasarkan observasi, guru juga kurang dalam menggunakan media pembelajaran, maka dari itu model SAVI akan lebih efektif jika proses pembelajaran dipadukan dengan media pembelajaran yang cocok agar proses pembelajaran lebih bervariasi serta nantinya dapat menarik minat belajar siswa. Falahudin (2014) menyatakan, media pembelajaran adalah media yang dapat memberikan informasi dari suatu sumber kepada penerima informasi. Sedangkan Maratusholihah, H., Priyanto, W., dan Damayani (2019), menyatakan media berperan penting pada proses pembelajaran karena keberadaan media dapat memperjelas materi yang dibelajarkan sehingga dapat meningkatkan motivasi siswa dalam belajar. Dari berbagai media yang ada, media yang cocok dipadukan dengan model pembelajaran SAVI adalah media mind mapping. Mind mapping merupakan cara kreatif dan efektif dalam membuat catatan, sehingga mind mapping dapat dikatakan sebagai alat memetakan pikiran (Hendrawan, G., dkk., 2018). Mind mapping dipadukan dengan model pembelajaran SAVI sangat cocok diterapkan untuk menanamkan konsep dan pemahaman konsep IPA agar peserta didik lebih mudah mengerti atau memahami materi yang diajarkan(Zuhdiana, A. A., dan Lilik, 2017).

Nureva \& Citra (2017) menyatakan bahwa mind mapping adalah suatu alat bantu untuk menggali kreativitas peserta didik untuk berfikir tentang suatu materi yang sudah dijelaskan maupun materi yang belum dijelaskan oleh gurunya di sekolah. Dalam penerapan media ini siswa dapat memahami materi dengan cara membuat ringkasan materi yang dapat dituangkan dalam bentuk gambar. Oleh karena itu, media mind mapping sangat cocok untuk diterapkan pada pembelajaran IPA karena, mind mapping dapat membuat materi pembelajaran menjadi berpola secara visual dan grafis yang nantinya dapat membantu siswa untuk mengingat dan memperkuat kembali tentang informasi yang didapatkan dari guru maupun sumber informasi tertentu. Penggunaan gambar dan warna pada pembelajaran dapat memberikan kontribuis yang baik, yaitu meningkatkan gairah siswa (Birren dalam Nengsih, 2016). Media ini juga dapat membuat kemampuan otak kanan dan otak kiri siswa menjadi kreatif karena media ini menggunakan warna, gambar, imajinasi yang dimiliki, dan bahasa dan dapat membantu siswa untuk mengingat lebih lama materi yang telah dipelajari oleh siswa (Nengsih, 2016).

Model pembelajaran SAVI berbantuan media mind mapping diyakini dapat sebagai salah satu upaya dalam meningkatkan hasil belajar IPA, hal ini telah dibuktikan oleh penelitian Sulaksana, Y. T.,, dkk (2018) yaitu adanya perbedaan signifikan hasil belajar IPA antara siswa yang mengikuti pembelajaran konvensional dengan siswa yang menerapkan 
model pembelajaran SAVI berbantuan LKS. Perbedaan penelitian ini dengan penelitian yang sejenis adalah penggunaan model pembelajaran SAVI berbantuan media mind mapping. Penggunaan model pembelajaran yang dimodifikasi dengan menggunakan media mind mapping diharapkan mampu menjadikan siswa lebih memahami materi yang disampaikan guru. Meningkatkan hasil belajaran siswa dan saling berinteraksi dan berkomunikasi antar siswa dan guru. Berdasarkan pemaparan diatas, maka dilakukan penelitian tentang Pengaruh Model Pembelajaran SAVI Berbantuan Media Mind Mapping Terhadap Hasil Belajar IPA Siswa Kelas V Gugus II Kecamatan Tegallalang Tahun Pelajaran 2019/2020.

\section{Metode}

Desain penelitian ini adalah quasi eksperiment dengan menggunakan rancangan nonequivalent posttest only control grup design. Sukardi (2014) menyatakan populasi adalah semua anggota kelompok manusia, hewan, pristiwa, benda, yang menjadi target penelitian. Sedangkan Riduwan (2013),Populasi merupakan objek atau subjek yang berada pada suatu wilayah dan memenuhi syarat-syarat tertentu untuk dijadikan masalah penelitian. Populasi dalam penelitian ini adalah semua siswa kelas V di Gugus III Kecamatan Tegallalang yang terdapat 5 sekolah diantaranya, SD Negeri 1 Sebatu, SD Negeri 2 Sebatu, SD Negeri 3 Sebatu, SD Negeri 4 Sebatu, dan SD Negeri 5 Sebatu. Jumlah populasi dalam penelitian ini adalah 104 siswa. Kelas yang diikutkan dalam populasi akan diuji kesetaraan terlebih dahulu dengan menggunakan ANAVA satu jalur. Harga $F_{\text {hitung }}$ lebih kecil daripada $F_{\text {tabel }}(0.315<$ 2,46 ), pada taraf signifikansi $5 \%$ ), maka $\mathrm{HO}$ diterima dan Ha ditolak. Berdasarkan hal tersebut, hasil belajar IPA siswa kelas V Gugus III Kecamatan Tegallalang dinyatakan Setara.

Setelah mengetahui populasi langkah selanjutnya adalah menentukan sampel penelitian. Menurut Agung (2014), sampel adalah sebagian dari populasi yang diambil, yang mewakili seluruh populasi dan diambil menggunakan teknik tertentu. Pemilihan sampel dilakukan pada penelitian ini adalah teknik cluster random sampling. Setelah dilakukan cluster random sampling kemudian sekolah yang keluar sebagai kelompok eksperimen adalah SD Negeri 4 Sebatu dengan jumlah siswa 19, sedangkan sebagai kelompok kontrol yaitu SD Negeri 1 Sebatu dengan jumlah siswa 21, sehingga total sampel dalam penelitian ini yaitu 40 siswa.

Dalam penelitian ini, metode yang digunakan untuk mengumpulkan data adalah metode tes, dengan jenis tes menggunakan tes pilihan ganda. Tes hasil belajar yang dibuat disesuaikan dengan indikator yang mengacu pada taksonomi bloom dengan retangan tingkat kognitif mulai dari C3- C6. Tes hasil belajar IPA yang telah selesai disusun kemudian harus melalui beberapa uji sebelum digunakan. Pertama dilakukan uji validitas isi oleh pakar yang membidangi IPA. Perhitungan uji validitas isi mengunakan rumus Gregory dan hasilnya intrumen yang dibuat memiliki koefisien 1,00 yang berarti instrumen ini termasuk dalam kategori sangat baik. Kedua dilakukan uji validitas butir tes. Perhitungannya menggunakan bantuan program komputer Microsoft Office Excel 2007 for Windows, hasilnya dari 40 soal yang telah diujikan ke sekolah, ternyata 10 soal dinyatakan tidak valid dan 30 soal dinyatakan valid. Ketiga dilakukan uji reliabilitas butir tes. Perhitungannya menggunakan bantuan program komputer Microsoft Office Excel 2007 for Windows, hasilnya instrumen yang diuji memiliki reliabilitas 0,91 , artinya instumen ini berada pada derajat reliabilitas sangat tinggi.

Setelah dilaksanakan pengumpulan data selanjutnya data tersebut dianalisis menggunakan metode analisis deskriptif dan uji prasyarat dan dilakukan uji prasyarat analisis. Adapun uji prasyarat analisis yang digunakan yaitu uji normalitas sebaran data yaitu menggunakan analisis Chi-Kuadrat dengan kriteria pengujan jika $X_{\text {hitung }}$ lebih kecil daripada $X_{\text {tabel }}$ maka sampel berdistribusi normal. Uji prasyarat analisis yaitu uji homogenitas dengan analisis Fisher dengan kriteria pengujian jika $X_{\text {hitung }}$ lebih kecil daripada $X_{\text {tabel }}$ maka kelompok

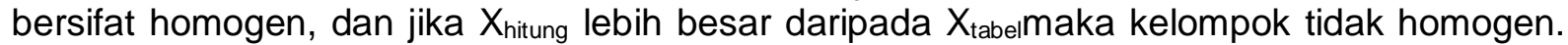
Setelah pengujian prasyarat terpenuhi, maka langkah selanjutnya dilakukan pengujian hipotesis penelitian ( $\mathrm{Ho})$ dan $(\mathrm{Ha})$. Teknik analisis data yang digunakan untuk menguji 
hipotesis dari penelitian ini adalah menggunakan uji-t independen. Teknik analisis data pada penelitian ini dihitung dengan bantuan Microsoft Excel for Window.

\section{Hasil dan Pembahasan}

Berdasarkan analisis deskriptif pada skor post-test siswa kelompok eksperimen didapat mean yaitu 24,74 median sebesar 24,17 , dan modus sebesar 24 . Pada kelompok kontrol didapat hasil analisis deskriptif yaitu mean yaitu 22,23 median sebesar 22,69, dan modus sebesar 23,92 . Pada hasil uji normalitas data dengan menggunakan teknik analisis Chi Kuadrat diperoleh $\mathrm{X}_{\text {hitung }}$ sebesar 2,22 dan $\mathrm{X}_{\text {tabel }}$ diperoleh 5,99, hal ini berarti $\mathrm{X}_{\text {hitung }}$ lebih kecil dari $X_{\text {tabel }}$ sehingga data posttest eksperimen berdistribusi normal, sedangkan pada kelompok kontrol diperoleh $X_{\text {hitung }}$ sebesar 5,31dan $X_{\text {tabel }}$ diperoleh 5,99, hal ini berarti $X_{\text {hitung }}$ lebih kecil dari $X_{\text {tabel }}$ sehingga data posttest eksperimen berdistribusi normal. Pada uji homogenitas dilakukan dengan menggunakan uji F. Berdasarkan perhitungan diproleh

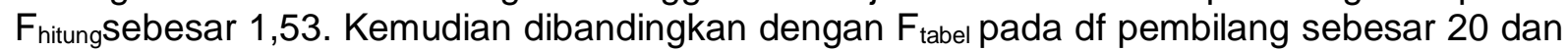
df penyebut 19. $F_{\text {tabel }}=F(0,05 ; 20 ; 19)=2,19$. Karena $F_{\text {hitung }}<F_{\text {tabel }}$ data posttest mempunyai varians yang sama atau homogen. Berdasarkan hasil perhitungan uji normalitas data dan uji homogenitas maka kedua kelompok dapat melakukan uji hipotesis.

Setelah dilakukan uji normalitas dan homogenitas selanjutnya dilakukan uji homogenitas dengan menggunakan uji t. Kriteria pengujiaannya adalah $\mathrm{H}_{0}$ diterima jika thitung $\leq t_{\text {tabel. }}$. Sebaliknya jika $t_{\text {hitung }}>t_{\text {tabel }}$ maka $\mathrm{H}_{0}$ ditolak. Adapun bunyi hipotesis yang diuji sebagi berikut. $\mathrm{H}_{0}$ : tidak terdapat perbedaan yang signifikan hasil belajar IPA antara kelompok siswa yang dibelajarkan dengan model pembelajaran SAVI berbantuan media mind mapping dan kelompok siswa yang dibelajarkan tidak dengan model pembelajaran SAVI berbantuan media mind mapping siswa kelas V SD di Gugus III Kecamatan Tegallalang Tahun Pelajaran 2019/2020. Sedangkan $H_{1}$ : Terdapat perbedaan yang signifikan hasil belajar IPA antara kelompok siswa yang dibelajarkan dengan model pembelajaran SAVI berbantuan media mind mapping dan kelompok siswa yang dibelajarkan tidak dengan model pembelajaran SAVI berbantuan media mind mapping siswa kelas V SD di Gugus III Kecamatan Tegallalang Tahun Pelajaran 2019/2020. Berdasarkan hasil perhitungan dengan bantuan program Microsoft Excel for Window didapat hasil sebagai berikut.

Tabel 3. Hasil Uji Hipotesis

\begin{tabular}{cccc}
\hline$t_{\text {hitung }}$ & Dk & $t_{\text {tabel }}$ & Keterangan \\
\hline 2,98 & 38 & 2,02 & Signifikan \\
\hline
\end{tabular}

Berdasarkan hasil analisis uji-t diperoleh $t_{\text {hitung }}=2,98$ sedangkan nilai $t_{\text {tabel }}$ pada taraf signifikan $5 \%$ dengan derajat kebebasan $(n 1+n 2-2)=19+21-2=38$ adalah 2,02, Berdasarkan $\mathrm{t}_{\text {hitung }}=2,98>\mathrm{t}_{\text {tabel }}=2,02$ maka $\mathrm{H}_{0}$ ditolak atauterdapat perbedaan yang signifikan hasil belajar IPA antara kelompok siswa yang dibelajarkan dengan model pembelajaran SAVI berbantuan media mind mapping dan kelompok siswa yang dibelajarkan tidak dengan model pembelajaran SAVI berbantuan media mind mapping siswa kelas V SD di Gugus III Kecamatan Tegallalang Tahun Pelajaran 2019/2020. Hasil tersebut menunjukkan hasil yang sama dengan penelitian yang dilakukan oleh Budiyanti, Y., dan Khairunnisa (2019) bahwa tingkat pemahaman konsep IPA setelah dibelajarkan dengan menggunakan model pembelajaran SAVI meningkat $85 \%$ dengan rata-rata sebesar 84 , yang sebelumnya mendapat rata-rata $65 \%$. Penelitian yang dilakukan oleh Sutarna, N (2018) menunjukkan kesimpulan bahwa terdapat perbedaan yang signifikan rata-rata nila pretest dan posttest antara hasil belajar siswa sebelum dan sesudah menerapkan model pembelajaran SAVI.

Berdasarkan hasil temuan peneliti pada kelompok eksperimen dan kelompok kontrol yang awalnya menunjukkan kemampuan yang setara dan ternyata setalah diberikan perlakuan dengan menggunakan model pembelajaran SAVI berbantuan media mind mapping mengalami perbedaan. Model pembelajaran SAVI berbantuan media mind mapping dapat membuat siswa untuk menemukan pengetahuan dan keterampilan baru dalam proses 
pembelajaran yang melalui beberapa tahap dari model pembelajaran SAVI. Tahapan tersebut tahap persiapan, tahap penyampaian, tahap pelatiahan dan tahap penampilan hasil dengan unsur-unsur Somatic, Auditory, Visualitation, Intelektually pada beberapa tahapannya.

Pada tahapan persiapan, guru meminta siswa untuk mempersiapkan alat-alat pembelajaran sehingga pada proses pembelajaran siswa benar-benar siap dalam mengikuti proses pembelajaran yang diberikan oleh guru. Sambil mempersiapkan sarana pembelajaran guru mengajukan pertanyaan-pertanyaan yang dapat merangsang siswa untuk berpikir dan membangkitkan rasa ingin tahu siswa sehingga siswa termotivasi dalam mengikuti proses pembelajaran maupun materi yang akan dipelajari. Pertanyaan-petanyaan yang diajukan menyangkut pengalaman siswa dan hal-hal yang relevan dan tidak membuat siswa memiliki perasaan negative terhadap proses pembelajaran. Karena pendapat Meier (2004), menyatakan dalam langkah memulai pembelajaran akan sangat menentukan proses pembelajaran berikutnya. Sesuai pandangan Susanto (2013) bahwa faktor yang mempengaruhi proses pembelajaran siswa yaitu salah satunya faktor internal seperti motivasi, minat dan perhatian, maka dari itu guru sangat perlu melakukan persiapan untuk menarik minat siswa. Pada tahap ini peneliti menemukan adanya respon positif yang ditunjukkan aktivitas siswa dalam mencari jawaban dari pertanyaan guru.

Tahap penyampaian guru memberikan inti dari materi yang akan dibahas dengan bertanya jawab kepada siswa (visual dan auditori). Penyampaian materi yang dilakukan dengan tanya jawab akan mampu melatih kemampuan kognitif yang dimiliki oleh siswa. Proses tanya jawab akan membuat siswa menggali pengetahuan dan mencari informasi atau sumber-sumber untuk menjawab pertanyaan yang diberikan oleh guru. Dengan demikian pengetahuan dan keterampilan yang didapat oleh siswa akan sangat bermakna, hal tersebut juga akan membuat siswa tidak pasif menerima informasi dari guru. Pembelajaran IPA mengharuskan siswa untuk berkegiatan seperti penelitian, percobaan, dan memecahkan masalah, melalui diskusi tanya jawab siswa akan diasah cara penyelesaian masalahnya (Nurveva \& Citra, 2017).

Tahap pelatihan, siswa diberikan beberapa pertanyaan yang berbentuk bagan dengan kolom-kolom yang akan membuat siswa untuk terlatih menemukan konsep baru dengan cara yang menarik. Setelah siswa mendapatkan jawaban, jawaban tersebut dituangkan dalam bentuk mind mapping. Dalam membuat mind mapping siswa akan menuangkan ide dan imajinasinya ke dalam mind mapping sehingga nantinya pengetahuan yang didapat oleh siswa mampu diingat dalam waktu jangka panjang karena di dalam media mind mapping siswa menentukan konsep dan meringkas jawaban dari pertanyaan-pertanyaan yang diberikan oleh guru. Selain itu pelajaran yang memberikan kesempatan kepada siswa untuk terlibat langsung dalam proses pembelajaran akan melatih siswa untuk menemukan konsep baru secara individu. Pada tahap ini siswa melakukan unsur Intelectualy dan Somatic yang diartikan dengan suatu proses pembelajaran yang siswa lakukan dengan cara menghubungkan pengalaman mental, fisik, emosional dan intiuitif tubuh melalui mind mapping. Mind mapping dapat melipat gandakan kemampaun otak kanan siswa dan otak kiri, karena dalam proses pembelajarannya siswa dihadapkan dengan warna, gambar, imajinasi dan bahasa (Gunawan, 2015). Menurut Andriani proses belajar IPA diarahkan pada kegiatan-kegiatan yang mendukung pemahaman terhadap teori, dasar dan prosedur yang berkaitan dengan kehidupan sehari-hari peserta didik. (Meier, 2004) berpendapat bahwa salah satu prinsip dasar SAVI yaitu belajar adalah berkreasi dan bukan mengonsumsi, dengan siswa membuat mind mapping akan terjadi keterampilan baru dan siswa mampu memadukan pengetahuan ke dalam struktur siswa yang telah ada.

Tahap Penampilan hasil, pada tahap ini guru mengajak siswa untuk berani berpendapat dan percaya diri dalam presentasi atau maju ke depan kelas. Dalam tahap ini guru juga dapat membimbing siswa untuk belajar menyimpulkan apa yang telah mereka pelajari. Media mind mapping yang telah dibuat selanjutnya dibawa ke rumah agar siswa punya konsep dalam mempelajari sesuatu. Setelah itu guru memberikan evalusi pada akhir pembelajaran. Evaluasi yang diberikan guru bertujuan untuk mengetahui sejauh mana 
pemahaman materi yang telah dipelajari oleh siswa. Evalusi ini sangat penting dilakukan karena disini guru dapat mengetahui sejauh aman keberasilan atau tindakan suatu proses pembelajaran sehingga nantinya dapat ditingkatkan kembali. Sesuai dengan pendapat Suwadi (2011) yang menyatakan penilaian evaluasi sangat penting dilakukan untuk melihat keberhasilan suatu kegiatan pembelajaran.

Berdasarkan langkah-langkah model pembelajaran SAVI berbantuan media mind mapping yang telah dipaparkan, maka langkah-langkah model pembelajaran SAVI berbantuan media mind mapping sangat cocok dengan karakteristik IPA yang menekankan keaktifan siswa dalam proses pembelajaran. Model pembelajaran SAVI berbantuan media mind mapping yang telah diterapkan memberikan ruang gerak kepada siswa untuk membangun pengetahuannya sendiri. Selain itu model pembelajaran SAVI berbantuan media mind mapping merupakan model pembelajaran yang inovatif dan mampu membuat siswa memanfaatkan seluruh alat indranya dalam mengikuti proses pembelajaran. Alat indra yang harus dimanfaatkan secara optimal oleh siswa agar siswa secara individu dapat menemukan konsep maupun memecahkan masalah yang dihadapinya.

Adapun kelebihan dari model pembelajaran SAVI menurut Alfiani, D. A. (2016) adalah membangkitkan kecerdasan terpadu siswa secara penuh melalui penggabungan gerak fisik dengan aktivitas intelektual, didesain agar suasana belajar menjadi menyenangkan, menarik, sehingga siswa tidak mudah lupa karena semua proses pembelajaran tersebut melekat pada diri mereka, mampu membangkitkan kreativitas dan meningkatkan kemampuan psikomotor siswa, memaksimalkan ketajaman konsentrasi siswa, siswa akan termotivasi untuk belajar lebih baik, melatih siswa untuk terbiasa mengemukakan pendapat, bertanya, maupun menjawab, dan kelebihan yang sangat kuat adalah merupakan variasi yang cocok untuk semua gaya belajar. Selain itu hasil penelitian ini juga didukung dengan hasil penelitian dari Yudiari dkk (2015) yang menunjukkan bahwa hasil penelitian dengan menggunakan model pembelajaran SAVI berbantuan mind mapping dapat meningkatkan hasil belajar siswa dibandingkan dengan pembelajaran yang tidak menggunakan model pembelajaran SAVI berbantuan media mind mapping. Hal ini karena model pembelajaran SAVI mengajak siswa langsung terlibat dalam pembelajaran baik secara pisik maupun secara intelektual dan dibarengi dengan menggunakan mind mapping menjadikan pembelajaran lebih menarik.

Sementara itu, hasil penelitian Selanjutnya, Dewi \& Riandi (2016), menunjukan terjadi peningkatan keterampilan berpikir kompleks seiring diterapkannya pembelajaran berbasis masalah yang dikombinasikan dengan mind mapping. Selanjutnya, Adiyatmaningsih dkk(2014)menyatakan penerarapan pembelajaran berbasis masalah berbantuan mind mapping meningkatkan hasil belajar IPA siswa. Lebih lanjut, Sukardi, dkk (2015) menjelaskan, terdapat peningkatan keterampilan metakognitif dan hasil belajar yang signifikan dengan penerapan pembelajaran reciprocal teaching berbantuan peta pikiran.

Sesuai dengan penjelasan tesebut, terdapat perbedaan yakni pada kelompok kontrol dan kelompok eksperimen. Hal tersebut juga dapat dilihat sesuai dengan rata-rata nilai kompetensi pengetahuan IPA pada kedua kelompok yaitu pada kelompok eksperimen 24,74 dan pada kelompok kontrol 22,32. Hasil tersebut menunjukkan bahwa hasil belajar siswa kelompok eksperimen lebih tinggi dibandingkan dengan hasil belajar siswa pada kelompok kontrol dalam kompetensi pengetahuan IPA. Hal tersebut juga sesuai dengan penelitian yang dilakukan Ramadhani (2017) yang hasil penelitiannya menujukkan bahwa terdapat perbedaan yang signifikan siswa yang dibelajarkan dengan model pembelajaran SAVI dan media benda konkret dengan siswa yang tidak dibelajarkan menggunakan model pembelajaran SAVI dan media benda konkret. Selain Ramadhani, Mei Yudiari juga mendapatkan hasil yang sama, yaitu menunjukkan adanya hasil yang berbeda secara signifikan antara kolompok eksperimen dan kelompok kontrol di SD Gugus II Kecamatan Mendoyo pada hasil belajar IPA siswa kelas V.

Dengan demikian proses pembelajaran yang menerapkan model pembelajaran SAVI berbantuan media mind mapping pada penelitian ini memiliki keunggulan yaitu dapat melatih siswa untuk aktif dan kreatif dalam mengikuti proses pembelajaran. Selain itu model ini juga dapat mengasah otak kanan dan otak kiri yang dimiliki oleh setiap individu siswa. Model pembelajaran SAVI berbantuan media mind mapping juga dapat melatih siswa untuk 
memanfaatkan seluruh alat indra yang dimiliki. Berdasarkan pemaparan tersebut, pembelajaran menggunakan model pembelajaran SAVI berbantuan media mind mapping pada penelitian ini berpengaruh terhadap hasil belajar muatan materi IPA yang dimiliki oleh siswa serta dapat meningkatkan antusias siswa dalam mengikuti pembelajaran.

\section{Simpulan}

Berdasarkan rumusan masalah dan hasil penelitian dapat disimpulkan bahwa terdapat perbedaan hasil belajar IPA antara kelompok eksperimen yang dibelajarkan dengan model SAVI berbantuan mind mapping dan kelompok kontrol yang tidak dibelajarkan dengan menggunakan model model SAVI berbantuan mind mapping. Hal tersebut terlihat dari perbedaan rata-rata skor hasil belajar IPA siswa antara siswa yang dibelajarkan menggunakan model pembelajaran model SAVI berbantuan mind mapping dan siswa yang tidak dibelajarkan dengan model tersebut. Rata-rata skor kelompok eksperimen lebih tinggi dari pada rata-rata skor hasil belajar IPA kelompok kontrol. Berdasarkan simpulan sebelumnya, maka saran dapat diajukan kepada berbagai berikut. Berdasarkan temuan yang diperoleh, kepada guru disarankan agar lebih kreatif dalam memberikan fasilitas berupa sumber belajar dan kesempatan yang lebih besar bagi siswa dalam pembelajaran dengan menggunakan model pembelajaran SAVI berbantuan media mind mapping sehingga dapat mengaktifkan siswa dalam proses pembelajaran. Kepada kepala Sekolah diharapkan agar dapat digunakan sebagai sumber pendukung dalam proses pembelajaran di sekolah maupun di luar sekolah dan penelitian ini dapat digunakan sebagai sumber oleh guru kelas dalam meningkatkan proses pembelajaran dengan menciptakan pembelajaran yang menyenangkan sehingga sekolah mampu menghasilkan siswa yang berkualitas. Kepada peneliti lain disarankan agar hasil penelitian ini digunakan sebagai referensi penelitian yang relevan untuk melaksanakan penelitian selanjutnya atau menemukan inovasi kegiatan pembelajaran lainnya yang bermakna bagi siswa.

\section{Daftar Pustaka}

Adiyatmaningsih, N. P. H., Suara, I. M., \& Kristiantari, M. R. (2014). Model Pembelajaran Berbasis Masalah Berbantuan Mind Mapping Berpengaruh terhadap Hasil Belajar IPA Siswa Kelas V SD Gugus III Gianyar. MIMBAR PGSD Undiksha, 2(1).

Agung, G. (2014). Metododologi Penelitian Pendidikan. Aditya Media Publishing.

Alfiani, D. A. (2016). Penerapan Model Pembelajaran SAVI (Somatis, Auditori, Visual, Intelektual) terhadap Hasil Belajar Anak Usia Dini. Syekhnurjati.

Ariyanto, M. (2016). Peningkatan Hasil Belajar IPA Materi Kenampakan Rupa Bumi Menggunakan Model Scramble. Profesi Pendidikan Dasar, 3.

Budiyanti, Y., dan K. (2019). Upaya Meningkatkan Pemahaman Konsep Melalui Model Pembelajaran Somatic, Auditory, Visualiztion, Intellectualy (SAVI) Pada Mata Pelajaran IPA Siswa Kelas V MI Mifttahul Huda Kota Bekasi. PEDAGOGIK, VII.

Bundu, P. (2006). Penilaian Keterampilan Proses dan Sikap IImiah dalam Pembelajaran Sains Sekolah Dasar. Departemen Pendidikan Nasional, Direktorat Jenderal Pendidikan Tinggi, Direktorat Ketenagaan.

Devitasari, dkk. (2019). Keefektifan Model SAVI Terhadap Minat dan Hasil Belajar IPA SDN Lawatan 01 Kabupaten Tegal. Indonesian Journal of Conservation, 8.

Dewi, N., \& Riandi, R. (2016). Analisis Kemampuan Berpikir Kompleks Siswa Melalui Pembelajaran Berbasis Masalah Berbantuan Mind Mapping. EDUSAINS, 8(1), 98-107.

Falahudin, I. (2014). Pemanfaatan Media dalam Pembelajaran. Lingkar Widyawiswara.

Fatmah, A. N., dkk. (2018). Pengaruh Strategi PAIKEM (Pembelajaran Aktif, Inovatif, Kreatif, Efektif, Menyenangkan) terhadap Motivasi dan Hasil Belajar Siswa. Prosiding Seminar Nasional Biologi Dan Pembelajaran.

Fiteriani, I.., dan B. (2018). Konsepsi Penerapan Keterampilan Proses Sains (KPS) dan Sikap Ilmiah Dalam Desain Pengembangan Modul Panduan Eksperimen IPA SD/MI. Jurnal Pendidikan Dan Pembelajaran Dasar, 11.

Gunawan, H. (2015). Rahasia Mendapatkan Nilai 100. Sinotif Publishing. 
Hadi, S., dan Novaliyosi, N. (2019). TIMSS Indonesia (Trends In International Mathematic And Science Study). In Prosiding Seminar Nasional \& Call For Papers.

Hendrawan, G., dkk. (2018). Pengaruh Model Pembelajaran SAVI Berbasis Mind Mapping terhadap Motivasi Belajar IPS di SD. MIMBAR PGSD Undiksha, 6.

Hutauruk, P., dan Rinci, S. (2018). Meningkatkan Hasil Belajar Siswa dengan Alat Peraga pda Mata Pelajaran IPA kelas IV SDN Nomor 14 Simbolon Purba. SEJ (School Education Journal), 8.

Indrawan, dkk. (2018). Pengaruh Model Pembelajaran Somatic Auditory Visualization Intellectualy berbantuan Lingkungan Hidup terhadap Hasil Belajar IPA Siswa. Jurnal IImiah Sekolah Dasar, 2(1), 59-67.

Malawi, I., dan J. (2013). Pengaruh Pembelajaran Cooperatif Learning Type Make A-Match Terhadap Hasil Belajar IPA Kelas V SDN 01 Manisrejo Kota Madiun. Journal of Chemical Information and Modeling.

Maratusholihah, H., Priyanto, W., dan Damayani, A. T. (2019). Pengembangan Media Pembelajaran Tematik Ular Tangga Berbagai Pekerjaan. MIMBAR PGSD Undiksha, 7.

Meier, D. (2004). The Accelerated Learning Handbook. PT Mizan Pustaka.

Nengsih, W. (2016). Penerapan Metode Diskusi dengan Media Mind Mapping dalam Upaya Peningkatan Hasil Belajar. Jurnal Curricula, 2.

Nureva \& Citra. (2017). Pengaruh Penggunaan Model Pembelajaran Inkuiri Berbantuan Mind Mapping dan Picture Mapping Terhadap Hasil Belajar IPA Pada Siswa Kelas V Sekolah Dasar. Terampil Jurnal Pendidikan Dan Pembelajaran Dasar P-ISSN 2355-1925 e-ISSN 2580-8915, 4(2), 157-170.

Nurveva \& Citra. (2017). Pengaruh Penggunaan Model Pembelajaran Inkuiri Berbantuan Mind Mapping dan Picture Mapping terhadap Hasil Belajar IPA pada Siswa Kelas V Sekolah Dasar. Terampil Jurnal Pendidikan Dan Pembelajaran Dasar P-ISSN 23551925 e-ISSN 2580-8915, 4, 157-170.

Permana, Rakhmad, \& H. (2019). Survei Kualitas Pendidikan PISA 2018: RI Sepuluh Besar dari Bawah. Https://News.Detik.Com/Berita/d-4808456/Survei-Kualitas-Pendidikan-Pisa2018-Ri-Sepuluh-Besar-Dari-Bawah.

Pratiwi, I. (2019). Efek Program PISA Terhadap Kurikulum di Indonesia. Jurnal Pendidikan Dan Kebudayaan (Pusat Penelitian Kebijakan Pendidikan Dan Kebudayaan Badan Penelitian Dan Pengembangan Kementerian Pendidikan Dan Kebudayaan), 4, 51-71.

Ramadhani, A. (2017). Jurnal Pengaruh Model Pembelajaran Savi Dan Media Benda Konkret Terhadap Hasil Belajar Materi Sifat-Sifat Cahaya Pada Siswa Kelas V Sdn Ngadirejo Kota Kediri Tahun Pelajaran 2016 / 2017 the Effect of Savi Learning Model and Concrete Object Media Toward Le. Simki-Pedagogia, 01(08).

Sudana, dkk. (2016). Pendidikan IPA SD. Undiksha Press.

Sukardi. (2014). Metodelogi Penelitian Pendidikan. PT Bumi Aksara.

Sulaksana, Y. T., dkk. (2018). Pengaru Model Pembelajaran SAVI (Somatic Auditory Visualiztion Intellectualy) Berbantuan LKS Terhadap Hasil Belajar IPA. Jurnal Pedagogi Dan Pembelajaran, 1.

Suminar, D. A. R. (2018). Pengembangan Komik Sebagai Media Pembelajaran IPA Materi Gaya Magnet Kelas V SD Negeri Kepuh. Jurnal Pendidikan Guru Sekolah Dasar.

Susanto, A. (2013). Teori Belajar dan Pembelajaran di Sekolah Dasar. PT Fajar Interpratama Mandiri.

Sutarna, N. (2018). Pendidikan dasar. Profesi Pendidikan Dasar E-ISSN 2503-3530 p-ISSN 2406-8012, 5(2), 109-118. https://doi.org/DOI: https://doi.org/10.23917/ppd.v1i2.5877 PENGARUH

Suwadi, S. (2011). Model-model Assesmen Dalam Pembelajaran. Yuma Pustaka.

Widyanto, P. (2016). Penerapan Metode Pembelajaran Group Investigation Berbantuan Media Flanelgraf Untuk Meningkatkan Minat Dan Hasil Belajar Siswa Pada Mata Pelajaran IPA (Studi Kelas IV SDN Jetak 01, Kecamatan Getasan, Kabupaten Semarang). Jurnal Pendidikan Dasar Nusantara, 3(1), 118-129.

Yudiari, M. M., Parmiti, D. P., \& Sudana, D. N. (2015). Pengaruh Model Pembelajaran Savi Berbantuan Media Mind Mapping terhadap Hasil Belajar IPA Siswa Kelas V. MIMBAR 
PGSD Undiksha, 3(1).

Zuhdiana, A. A., dan Lilik, M. (2017). Penerapan Model Pembelajaran Mind Mapping dengan Media Kartu untuk Meningkatkan Hasil Belajar Siswa. Proceeding Biology Education Conference, 14. 